\title{
Impact of the Technological Path on Some Soil Properties on Loess Slope
}

\section{Edyta Kruk ${ }^{1}$}

1 Department of Land Reclamation and Environmental Development, Agriculture University of Krakow, Al. Mickiewicza 24/28, 30-059 Krakow, Poland, e-mail: e.kruk@ur.krakow.pl

\begin{abstract}
Investigations of horizontal and vertical changes of soil moisture and soil compaction on eroded loess slope, were the aim of the work. The study was performed on a farm in the municipality of Brzeźnica [N50 $8^{\prime} 33,03$, E18 $\left.8^{\circ} 3^{\prime} 16,31\right]$ (Province of Silesia, Poland). The research and collection of soil samples were carried out on 20.07.2017. On the day of the measurement, the slope was covered with winter wheat. The soil moisture and compaction degree were monitored at 36 points in the experimental area. The distance between the points along the slope were: $25 \mathrm{~m}$ (points: 1, 1a, 1b-6, 6a, 6b), $50 \mathrm{~m}$ (points: 6, 6a, 6b-11, 11a, 11b) and $200 \mathrm{~m}$ (points: $11,11 \mathrm{a}, 11 \mathrm{~b}-12,12 \mathrm{a}, 12 \mathrm{~b}$ ), while across the slope, the distances were $2 \mathrm{~m}$ apart. The vertical changes were determined based on the measurements at depths: $0-5,5-10,10-15,15-20,20-30,30-40,40-50$ and 50-60 $\mathrm{cm}$. Soil moisture were carried out using device of the TDR HH2 type. The soil moisture was ranged between $2.8 \%$ and $28.0 \%$. The degree of compaction was determining using the Eijkelkamp manual penetrometer up to a maximum depth of $80 \mathrm{~cm}$. The statistical analysis includes depths up to $30 \mathrm{~cm}$. The soil compaction values ranged between 0.24 and $2.66 \mathrm{MPa}$. There were large differences between the values of examined parameters both horizontally and vertically in relation to the location on the slope. The horizontal and vertical distributions of the investigated parameters were elaborated using the analysis of variance, three-way, where the independent factors were: road and location 2 and $4 \mathrm{~m}$ from it (factor A), depth (factor B), and position along the slope (factor $\mathrm{C}$ ). The analysis of variance showed that in the case of compaction, there is a statistically significant effect of the technical path and distance from it, and depth, on the formation of this property. In the case of soil moisture, the analysis of variance showed a statistically significant effect of the technical road and distance from it, as well as the depth, on the shaping of this property.
\end{abstract}

Keywords: soil moisture, soil compaction, manual penetrometer.

\section{INTRODUCTION}

The increase in the level of agricultural treatment and aspiration for yield growth caused the appearance of modern tractors and corn combines with large working width in agriculture. The process of transmission of energy to basis, which in most cases causes its compaction, has become the unintended effect. The compacted soil layer makes plant rooting, water and mineral compounds leading difficult, increases the risk of erosion and leaching of pesticides and nutrients to groundwater [Li et al. 2006, Halecki et al. 2018], which causes a decrease of the plant production capacity [Małecka et al. 2012]. In developed countries, all the soils exert a high level of compaction. Compaction is one of the most widespread form of soil psychical degradation in the Middle and East Europe. Over one-third of soils in Europe are very receptive to compaction in the bottom layers. In their investigations, Buliński and Marczuk [2009] showed that in corn breeding, in the traditional system of aggregates movement in field, trails of wheels covered from $54.5 \%$ to $61.4 \%$ of field area, while the total length of trails left on an area of 1 ha, according to investigations carried out by Powałka [2009] in the case of spring oat was $30 \mathrm{~km}$ [Zbytek and Talarczyk 2012]. At present, soil compaction can be counteracted by introduction to cultivation some simplifications, 
among others reducing the number of treatments and scarifying intensity, and even their total liquidation [Biskupski et al. 2009, Price and Theriot, 2003, Wesołowski and Cierpiała 2011]. One of the ways to limit soil compaction is movement of an aggregate along technological roads. As a result of this treatment, an area of field becomes covered by wheel trails. At present, the vehicular paths are presently the technical standard in achieving high and stable yields. The width of a path should be selected in such way, so that the width of a tire does not compact side rows and degrade plants. Broken plants have a tendency to weaker growth, uneven maturity and are prone to fungal diseases.

Soil compaction is one of the most important information needed for efficient soil and plant management and for wheel movement in a field. Proper analysis of the compaction process is enabled by the possibility to determine the temporary characteristics of soil for the comparison of various technical and technological solutions of field plant production. In this scope, the penetrometer measurements are of particular significance [Lejman et al. 2010]. The most frequent way to evaluate the soil reliability is to use the ground penetrometer, which characterises the force needed to stick cone of a given size. Numerous investigations were carried out to understand influence of bulk density and water content on the resistance of soil penetration in a laboratory [Busscher et al. 1997], which yielded both empirical and theoretical relationships. The resistance of soil to penetration is one of the most frequent used indices of the physical quality of soil in agronomical evaluations [Medeiros et. al. 2010]. It is one of the physical properties, directly influencing the root growth and yield. It is also used as the indicator of soil management systems influence [Dexter et al. 2007, Andrade et al. 2013].

For the negative influence of soil compaction connected with the limitation of air diffusion, the availability of water and nutrients and increased the mechanical resistance to root growth to be measured. Numerous scientists used the term of the least limiting water scope, in which the limitations of plant development regarding air, water availability and resistance to penetration are significantly decreased [Beutler et. al. 2014]. However, many others investigators defend a simpler concept, establishing critical values for the physical properties, such as bulk density and resistance of soil to penetration. In this way, when these properties exceed critical values, the growth of a plant is highly limited. Thus, determination of the compacted soil layers using simpler and portable penetrometers would be a proper and cheaper alternative. Similarly, various devices were tested to check deadweight load of soil [Ajayi and Horn 2016]. The latest achievements in the field of information technology significantly improved the ability of collection, transforming and analyzing of data from penetrometer. Digital data recorders and devices for depth measurement mobilized in real time connection of raw output data with penetration depth and calibration coefficients. Presently, there density, compactness, moisture and soil color can be forecast without the necessity of collecting soil samples. The changes of soil compaction are caused by the changes of soil wetness and bulk density, which is essential for planning agricultural treatments in proper values of these parameters, or if bulk density is reduced by a decreased amount of organic materials in soil or in cultivation.

Soil wetness is the yield creating agent connected with agricultural activity. Its proper level conditions the plant development, as well as changes the sensitivity to compaciton by wheels of agricultural machines [Buliński and Sergiel 2011]. It is pointed [Szeptycki 2003] that wetness influences the tension and its scope of propagation in the arable layer under the wheels of vehicles. Therefore, every soil has its own concrete wetness, at which its resistance to mechanical forces is the lowest. This wetness fluctuated between about $14 \%$ for loamy sand and sandy loam and $26 \%$ for silt and heavy loam. It was also stated [Włodek 2000] that the highest decrease of bulk density and decrease of porosity as a result of wheels movement occurs in the upper layer, and changes in the intensity were strictly connected with soil wetness [Buliński and Sergiel 2011].

In a modern approach of precision agriculture, producers can identify the changes and irregularities in a farm, and then undertake the activities aiming at increasing the yield by controlling such changes. In another ways, the modern agriculture is a strategy of management, which uses detailed information of every part of field and utilizes precise disbursals management.

The aim of the work was to assess the influence of technological road on the spatial change of soil compaction and volumetric wetness. 


\section{MATERIALS AND METHODS}

The study was performed on a farm in the municipality of Brzeźnica [N508'33.03, E18 $\left.{ }^{\circ} 3^{\prime} 16.31\right]$ (Province of Silesia, Poland) (Figure 1). Investigations and sampling were carried out on 20 July 2017. During the field measurement, the slope was covered by winter wheat.

The measuring points were located on the slope of eastern exposition, characterized by the mean decline of about $5 \%$. The following scheme of description was adopted in the work:

- for the points located along technical road: P1-P12;

- for the points located in a distance of $2 \mathrm{~m}$ from technical road P1-P12: P1a-P12a;

- for the points located in a distance of $4 \mathrm{~m}$ from technical road P1-P12: P1b-P12b (Figure 2).
Soil moisture and compaction degree were monitored at 36 points in the experimental side. The distance between points along the slope was: $25 \mathrm{~m}$ (points 1, 1a, 1b-6, 6a, 6b)), $50 \mathrm{~m}$ ((points $6,6 \mathrm{a}, 6 \mathrm{~b}-11,11 \mathrm{a}, 11 \mathrm{~b}$ ) and $200 \mathrm{~m}$ (points 11 , $11 \mathrm{a}, 11 \mathrm{~b}-12,12 \mathrm{a}, 12 \mathrm{~b}$ ), while across the slope, the points were 2 and $4 \mathrm{~m}$ far off the technical road. The volumetric water content was determined at the depths: $0-5 \mathrm{~cm}, 5-10 \mathrm{~cm}, 10-15 \mathrm{~cm}$, $15-20 \mathrm{~cm}, 20-30 \mathrm{~cm}$.

The compaction degree was determined by means of a CBR penetrologger produced by Eijkelkamp. The measurements were carried out by cone type $1.0 \mathrm{~cm}^{2}, 60^{\circ}$, with penetration speed $2.0 \mathrm{~cm} \cdot \mathrm{s}^{-1}$ at maximum penetration depth $80 \mathrm{~cm}$ (Figure 3). In statistical analysis, only the depth up to $30 \mathrm{~cm}$ was taken into consideration.

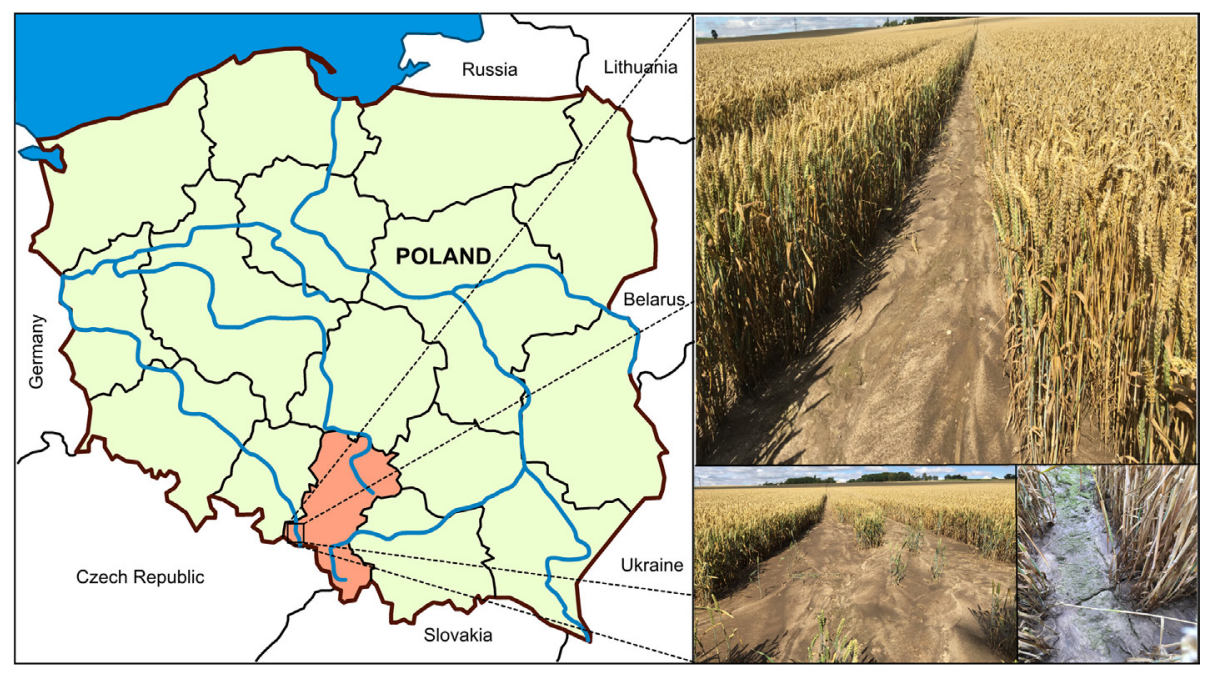

Figure 1. Location of the investigation side

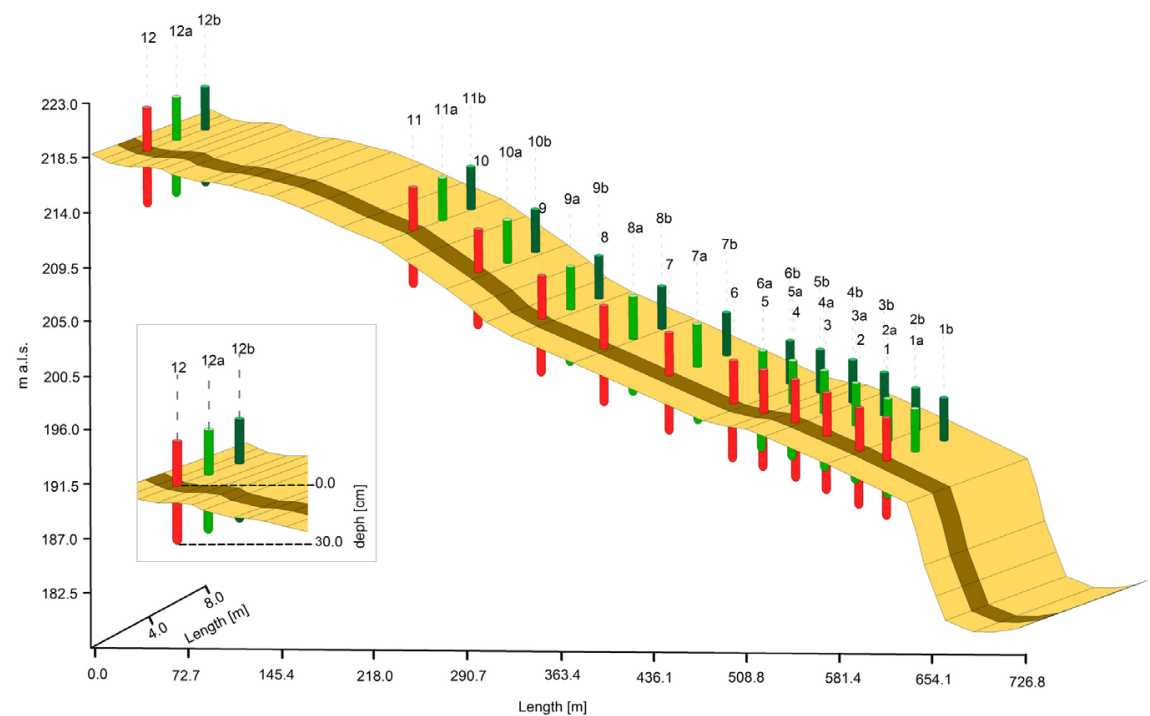

Figure 2. Location of measuring points 


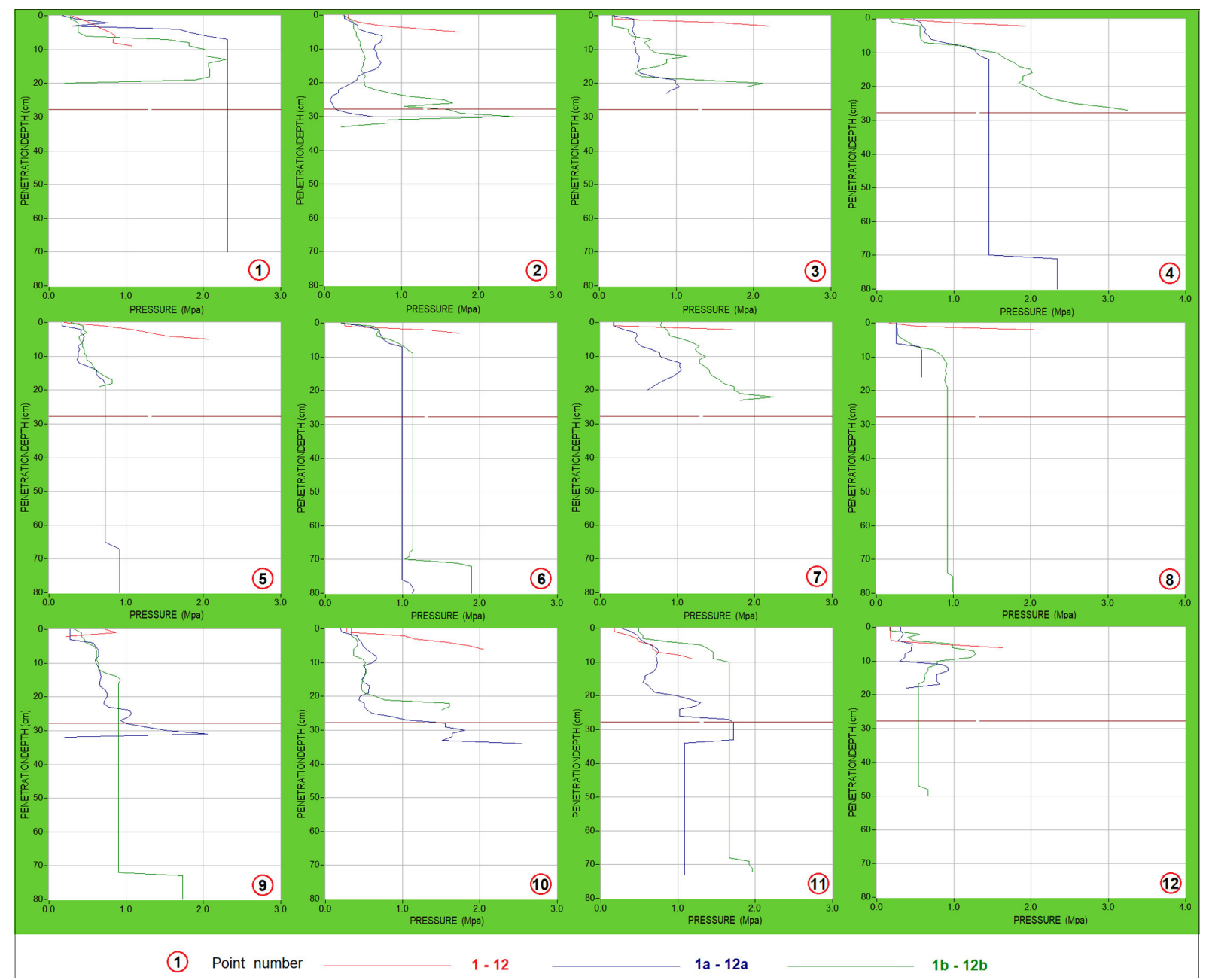

Figure 3. Compaction values in experimental side

The soil samples were taken in 12 points ( $\mathrm{P} 1-$ $\mathrm{P} 2$, P6, P10-P12; $\mathrm{P} 1_{b}-\mathrm{P} 2_{\mathrm{b}}, \mathrm{P} 6_{\mathrm{b}}, \mathrm{P} 10_{\mathrm{b}}-\mathrm{P} 12_{\mathrm{b}}$ ), at 5 depths $(0.5 \mathrm{~cm}, 5-10 \mathrm{~cm}, 10-15 \mathrm{~cm}, 15-20 \mathrm{~cm}$ and $20-30 \mathrm{~cm}$ ), using soil auger. The particle size analysis was performed by the Casagrande method [Mocek 2015]. Texture was classified according to PTG [2008].

The three-direction analysis of variance was used for the analyses of influence of technological road on soil compaction and volumetric water content; the independent factors were: road and distance 2 and $4 \mathrm{~m}$ (factor A), depth (factor B), location along the slope (factor $\mathrm{C}$ ). It can be described by the following model:

$$
\begin{gathered}
x_{i, j, k, l}=\mu+a_{i}+b_{j}+c_{k}+(a b)_{i, j}+ \\
+(a c)_{i, k}+(b c)_{j, k}+(a b c)_{i, j, k}+e_{i, j, k, l}
\end{gathered}
$$

where: $\mu$-mean value of population,

$a_{i}, b_{j}, c_{k}$ - effects of the following factors, $(a b)_{i, K^{\prime}}(a c)_{i, K^{\prime}}(b c)_{i, k}-$ interaction effects of two following factors, $(a b c)_{i, j, k}$ - interaction of three factors, $e_{i, j, k, l}$ - influence of random peculiar factors for 1-th element in subgroup $(\mathrm{i}, \mathrm{j}, \mathrm{k})$

Verification of the hypothesis of statistical essentiality of the following factors and their interactions was carried out based on the F (FisherSnedecor) test, at the essentiality level $\alpha=0.05$. Zero hypothesis was the equality of means in the particular groups and sub groups [Rudnicki 1992].

\section{RESULTS AND DISCUSSION}

The investigations did not show the occurrence of groundwater within soil profile. The investigated soils did not include skeleton particles $(\varnothing>2 \mathrm{~mm})$, and regarding sand ${ }_{2.0-0.05 \mathrm{~mm}}$ $(15-32 \%)$, silt ${ }_{0,05-0,002 \mathrm{~mm}}(58-78 \%)$ and clay $<0.002 \mathrm{~mm}$ (7-14\%) fraction content, they were classified to the following granular subgroups: loam silt (P1P2, P6, P10, P12; P1 $-\mathrm{P} 2_{\mathrm{b}}, \mathrm{P} 6_{\mathrm{b}}, \mathrm{P} 10_{\mathrm{b}}, \mathrm{P} 11_{\mathrm{b}}, \mathrm{P} 12_{\mathrm{b}}$ 
Table 1. Texture of soil

\begin{tabular}{|c|c|c|c|c|c|c|c|}
\hline \multirow{3}{*}{ Profile number } & \multirow{3}{*}{$\begin{array}{c}\text { Depth } \\
\mathrm{cm}\end{array}$} & \multicolumn{6}{|c|}{$\%$ fraction with diameter, $\mathrm{mm}$} \\
\hline & & \multicolumn{2}{|c|}{$2.0-0.05$} & \multicolumn{2}{|c|}{$0.05-0.002$} & \multicolumn{2}{|c|}{$<0.002$} \\
\hline & & $\mathrm{P} 1$ & $\mathrm{P} 1_{\mathrm{b}}$ & $\mathrm{P} 1$ & $\mathrm{P} 1_{\mathrm{b}}$ & $\mathrm{P} 1$ & $\mathrm{P} 1_{\mathrm{b}}$ \\
\hline \multirow{5}{*}{1} & $0-5$ & 22 & 22 & 69 & 68 & 9 & 10 \\
\hline & $5-10$ & 22 & 22 & 70 & 68 & 8 & 10 \\
\hline & $10-15$ & 19 & 20 & 71 & 70 & 10 & 10 \\
\hline & $15-20$ & 19 & 21 & 70 & 69 & 11 & 10 \\
\hline & $20-30$ & 16 & 17 & 74 & 74 & 10 & 9 \\
\hline \multirow{6}{*}{2} & & $\mathrm{P} 2$ & $\mathrm{P} 2_{\mathrm{b}}$ & P2 & $\mathrm{P} 2_{\mathrm{b}}$ & $\mathrm{P} 2$ & $\mathrm{P} 2_{\mathrm{b}}$ \\
\hline & $0-5$ & 22 & 18 & 69 & 73 & 9 & 9 \\
\hline & $5-10$ & 22 & 17 & 70 & 74 & 8 & 9 \\
\hline & $10-15$ & 21 & 23 & 70 & 68 & 9 & 9 \\
\hline & $15-20$ & 17 & 22 & 73 & 69 & 10 & 9 \\
\hline & $20-30$ & 16 & 18 & 74 & 74 & 10 & 8 \\
\hline \multirow{6}{*}{6} & & P6 & $P 6_{b}$ & P6 & $\mathrm{P} 6_{\mathrm{b}}$ & P6 & $\mathrm{P} 6_{\mathrm{b}}$ \\
\hline & $0-5$ & 17 & 16 & 75 & 75 & 8 & 9 \\
\hline & $5-10$ & 17 & 16 & 75 & 75 & 8 & 9 \\
\hline & $10-15$ & 15 & 18 & 78 & 73 & 7 & 9 \\
\hline & $15-20$ & 17 & 19 & 76 & 73 & 7 & 8 \\
\hline & $20-30$ & 18 & 17 & 75 & 75 & 7 & 8 \\
\hline \multirow{6}{*}{10} & & P10 & $\mathrm{P} 10_{b}$ & P10 & $\mathrm{P} 10_{b}$ & P10 & $\mathrm{P} 10_{\mathrm{b}}$ \\
\hline & $0-5$ & 19 & 17 & 71 & 74 & 10 & 9 \\
\hline & 5-10 & 19 & 16 & 70 & 75 & 11 & 9 \\
\hline & $10-15$ & 16 & 18 & 73 & 72 & 11 & 10 \\
\hline & $15-20$ & 16 & 17 & 73 & 75 & 11 & 8 \\
\hline & $20-30$ & 15 & 18 & 75 & 75 & 10 & 7 \\
\hline \multirow{6}{*}{11} & & P11 & $\mathrm{P} 11_{b}$ & P11 & $\mathrm{P} 11_{b}$ & P11 & $\mathrm{P} 11_{b}$ \\
\hline & $0-5$ & 20 & 16 & 71 & 75 & 9 & 9 \\
\hline & $5-10$ & 21 & 16 & 70 & 75 & 9 & 9 \\
\hline & $10-15$ & 17 & 18 & 69 & 72 & 14 & 10 \\
\hline & $15-20$ & 17 & 17 & 69 & 75 & 14 & 8 \\
\hline & $20-30$ & 13 & 18 & 75 & 75 & 12 & 7 \\
\hline \multirow{6}{*}{12} & & $\mathrm{P} 12$ & $\mathrm{P} 12_{b}$ & $\mathrm{P} 12$ & $\mathrm{P} 12_{\mathrm{b}}$ & $\mathrm{P} 12$ & $\mathrm{P} 12_{\mathrm{b}}$ \\
\hline & $0-5$ & 22 & 28 & 69 & 61 & 9 & 11 \\
\hline & $5-10$ & 21 & 27 & 70 & 63 & 9 & 10 \\
\hline & $10-15$ & 20 & 29 & 70 & 61 & 10 & 10 \\
\hline & $15-20$ & 16 & 32 & 74 & 58 & 10 & 10 \\
\hline & $20-30$ & 16 & 28 & 75 & 61 & 9 & 11 \\
\hline
\end{tabular}

and clay silt $\left(\mathrm{P} 11_{10-15 \mathrm{~cm}}, \mathrm{P} 11_{15-20 \mathrm{~cm}}\right)$. The location of P11 measuring point in relation to others caused a change of the soil subgroup from clay silt in 3 and 4 level into loam silt, respectively, as a result of transportation of soil material along the slope. This point was located at the end of the breakdown of the slope. Hence, the location of this point could have influenced the results (Table 1). The values of volumetric water content fluctuated between 2.8 (point $12_{20-30 \mathrm{~cm}}$ ) and $28.0 \%$ (point $1_{0-5 \mathrm{~cm}}$ ) (Table 2 ). The highest values were in layer $20-30 \mathrm{~cm}$ in point 12 , while the lowest one was in point 1 , in the layer $0-5 \mathrm{~cm}$. The values of compaction ranged between 0.24 (point $8_{\mathrm{a} 0-5 \mathrm{~cm}}$ ) and $2.66 \mathrm{MPa}$ (point $4_{\mathrm{b} 20-30 \mathrm{~cm}}$ ) (Figure 4) The highest values were observed at the depth between 20 to $30 \mathrm{~cm}$ in point 4 , while the lowest one at the depth to $5 \mathrm{~cm}$ in point 8 .

The analysis of variance (Table 3 ) showed that in the case of compaction, there is a statistically significant influence of technical road and distance from it and as well as depths on shaping of this property. A statistically significant interaction between road and distance from it and depths was noted as well. The interaction between all the factors was also statistically significant.

In the case of the volumetric water content, the analysis of variance showed a statistically significant influence of technical road and distance from it and depths on shaping this property. A statistically significant interaction of all the three factors was obtained (Table 4). 
Table 2. Values of volumetric water content

\begin{tabular}{|c|c|c|c|c|c|c|c|c|c|c|c|c|c|c|c|c|}
\hline \multicolumn{2}{|c|}{$\begin{array}{l}\text { Profile numer } \\
\text { Depth, } \mathrm{cm}\end{array}$} & 1 & 2 & 3 & 4 & 5 & 6 & 7 & 8 & 9 & 10 & 11 & 12 & Min, \% & Max, \% & Mean, \% \\
\hline \multirow{5}{*}{ - } & $0-5$ & 28.0 & 10.4 & 15.3 & 12.3 & 14.2 & 16.7 & 17.2 & 19.1 & 18.5 & 20 & 25.7 & 21 & 10.4 & 28.0 & 18.2 \\
\hline & $5-10$ & 22.8 & 12.8 & 14.2 & 13.4 & 14.5 & 16.8 & 17.3 & 19.5 & 19.2 & 17.4 & 19.4 & 16.8 & 12.8 & 22.8 & 17.0 \\
\hline & $10-15$ & 25.7 & 9.7 & 16.3 & 15.4 & 15.3 & 10.6 & 18.2 & 19.8 & 19.8 & 15.7 & 27 & 20.9 & 9.7 & 27.0 & 17.9 \\
\hline & $15-20$ & 27.9 & 13.9 & 17.4 & 16.2 & 16.2 & 8.3 & 19.1 & 20.2 & 20.4 & 9.9 & 26.5 & 15.6 & 8.3 & 27.9 & 17.6 \\
\hline & $20-30$ & 21.7 & 11.3 & 19.7 & 17.1 & 16.8 & 6.9 & 19.4 & 21.1 & 21.4 & 6.2 & 26.8 & 15.4 & 6.2 & 26.8 & 17.0 \\
\hline \multirow{5}{*}{ a } & $0-5$ & 19.5 & 14.7 & 13.8 & 14.5 & 15.2 & 17.4 & 16.8 & 18.8 & 17.2 & 18.0 & 27.3 & 10.4 & 10.4 & 7.3 & 17.0 \\
\hline & $5-10$ & 19.2 & 17.3 & 15.7 & 13.2 & 15.1 & 17.4 & 15.7 & 16.5 & 15.2 & 18.8 & 26 & 5.2 & 5.2 & 26.0 & 16.3 \\
\hline & $10-15$ & 24.0 & 15.6 & 16.8 & 13.8 & 14.4 & 16.3 & 13.1 & 15.7 & 14.2 & 18.9 & 27.8 & 3.2 & 3.2 & 27.8 & 16.2 \\
\hline & $15-20$ & 17.4 & 14.5 & 15.4 & 12.1 & 13.8 & 12.0 & 12 & 14.4 & 13.2 & 13.1 & 26.5 & 3.2 & 3.2 & 26.5 & 14.0 \\
\hline & $20-30$ & 10.7 & 7.7 & 15.3 & 11.7 & 12.4 & 6.0 & 11.7 & 12.5 & 11.1 & 9.2 & 13.8 & 2.8 & 2.8 & 15.3 & 10.4 \\
\hline \multirow{5}{*}{ b } & $0-5$ & 16.5 & 12.4 & 12.4 & 12.1 & 13.2 & 15.1 & 14.2 & 16.5 & 15.1 & 16.2 & 21.3 & 9.5 & 9.5 & 21.3 & 14.5 \\
\hline & $5-10$ & 15.4 & 10.8 & 11.5 & 10.5 & 11.2 & 14.2 & 13.2 & 15.2 & 15.2 & 15.1 & 18.3 & 8.4 & 8.4 & 18.3 & 13.3 \\
\hline & $10-15$ & 14.2 & 11.4 & 11.8 & 11.0 & 12.4 & 13.4 & 12.5 & 14.2 & 13.5 & 14.2 & 17.4 & 8.1 & 8.1 & 17.4 & 12.8 \\
\hline & $15-20$ & 11.1 & 9.5 & 10.7 & 9.5 & 10.2 & 10.7 & 11.4 & 13.5 & 14.1 & 14.3 & 15.2 & 7.2 & 7.2 & 15.2 & 11.5 \\
\hline & $20-30$ & 10.8 & 10.4 & 9.1 & 8.6 & 9.6 & 10.1 & 10.4 & 10.1 & 12.3 & 11.2 & 13.4 & 6.5 & 6.5 & 13.4 & 10.2 \\
\hline
\end{tabular}

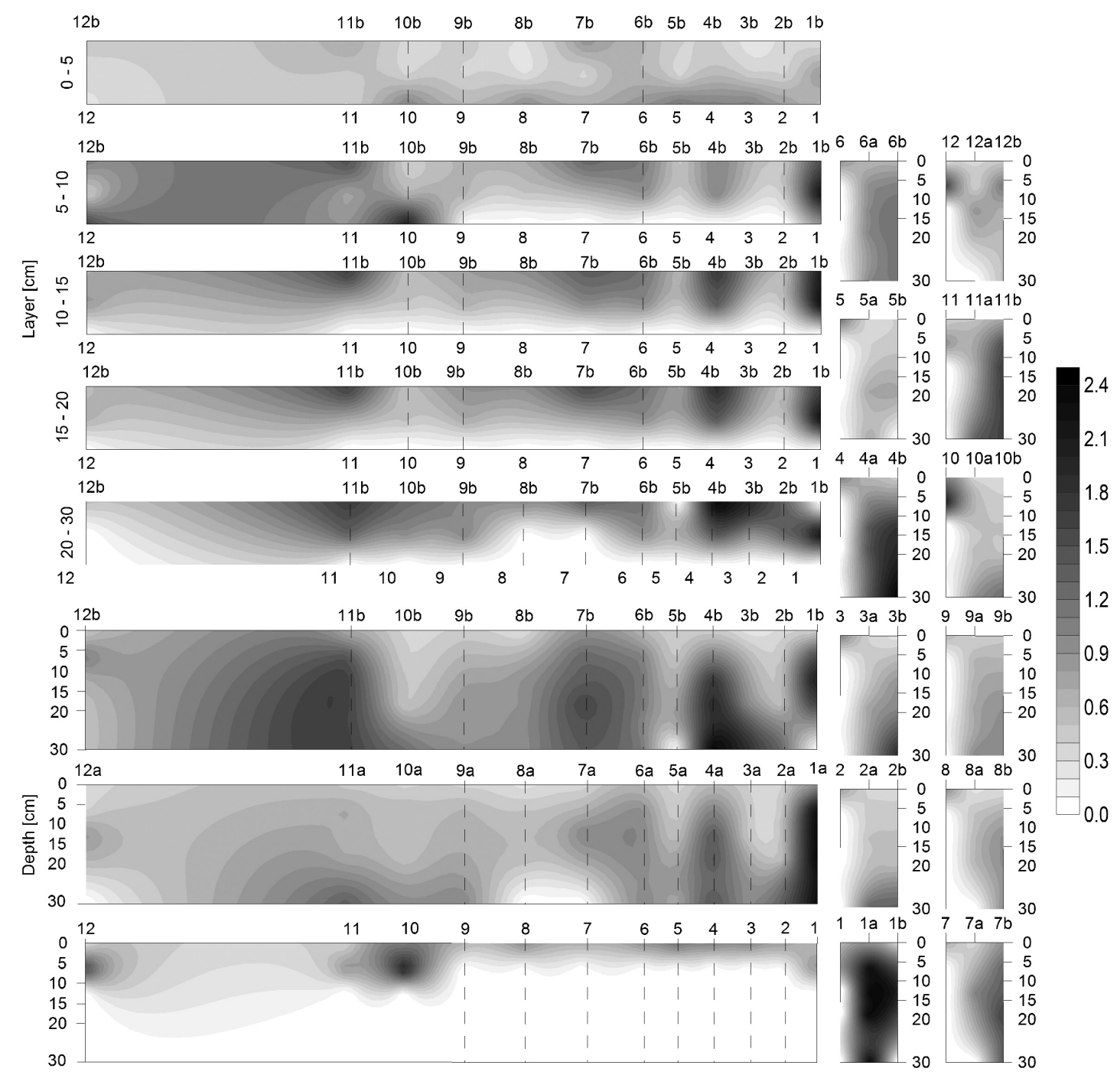

Figure 4. Values of compaction 
Table 3. Analysis of variance for compaction

\begin{tabular}{|c|c|c|c|c|c|}
\hline Source of variation & Sum of squares & Freedom degrees & Mean square & $\mathrm{F}_{\text {ob }}$ & $\mathrm{F}_{0.05}$ \\
\hline Factor A & 5.83 & 2 & 12.91 & $3.07^{*}$ & 3.04 \\
\hline Factor B & 13.63 & 4 & 3.41 & $3.59^{*}$ & 2.42 \\
\hline Factor C & 11.09 & 11 & 1.01 & 1.06 & 1.85 \\
\hline A B & 616.61 & 8 & 77.08 & $81.13^{*}$ & 1.98 \\
\hline A C & 16.63 & 22 & 0.76 & 0.80 & 1.6 \\
\hline B·C & 3.62 & 44 & 0.08 & 0.09 & 1.44 \\
\hline A B B C & 612.44 & 88 & 6.96 & $7.33^{*}$ & 1.33 \\
\hline Error & 171.82 & 180 & 0.95 & - & - \\
\hline Total & 226.80 & 359 & - & - & - \\
\hline
\end{tabular}

Table 4. Analysis of variance for volumetric water content

\begin{tabular}{|c|c|c|c|c|c|}
\hline Source of variation & Sum of squares & Freedom degrees & Mean square & $\mathrm{F}_{\text {obl }}$ & $\mathrm{F}_{0.05}$ \\
\hline Factor A & 6.78 & 2 & 3.39 & $3.90^{*}$ & 3.04 \\
\hline Factor B & 17.5 & 4 & 4.38 & $5.03^{*}$ & 2.42 \\
\hline Factor C & 10.25 & 11 & 0.93 & 1.07 & 1.85 \\
\hline A B & 187.12 & 8 & 23.39 & 26.89 & 1.98 \\
\hline A C & 18.7 & 22 & 0.85 & 0.98 & 1.60 \\
\hline B·C & 5.34 & 44 & 0.12 & 0.14 & 1.44 \\
\hline A B B C & 287.52 & 88 & 3.27 & $3.76^{*}$ & 1.33 \\
\hline Error & 156.02 & 180 & 0.87 & - & - \\
\hline Total & 2653.51 & 359 & - & - & - \\
\hline
\end{tabular}

* differences are statistically essential

\section{CONCLUSIONS}

1. Soil compaction showed the greatest values in the bottom part of the slope and in one point in upper part on the bend of the slope in the case of technical road, while in the case of the soil under wheat, the highest values occurred in the bottom part. In turn, while analyzing the values along the slope regarding depth, the highest ones were in the layers at the depth of $20-30 \mathrm{~cm}$.

2. The volumetric water content attained the highest values in the bottom and upper part of the slope in the case of the technical road and the same situation occurred in the case of soil under wheat. Generally, in comparison to the soil under wheat, higher values were found in the road at all depths.

3. The analysis of variance showed a statistically significant influence of the technical road as well as the distance from it and depths on the compaction and volumetric water content. A statistically significant difference in the interaction of all the factors was noticed.

\section{Acknowledgments}

Research was financed by the Ministry of Science and Higher Education of the Republic of Poland nr 4311.

\section{REFERENCES}

1. Ajayi A.E., Horn R. 2016. Comparing the potentials of clay and biochar in improving water retention and mechanical resilience of sandy soil. Int. Agrophys., 30, 391-399.

2. Andrade R.S., Stone L.F., Godoy S.G. 2013. Estimation of soil resistance to penetration based on the $\mathrm{S}$ index and effective stress. Revista Brasileira de Enegenharia Agrícola e Ambiental, 17(9), 932-937.

3. Biskupiński A., Włodek S., Pabin J. 2009. Wpływ zróżnicowanej uprawy roli na wybrane wskaźniki architektury łanu i plonowanie roślin. Fragm. Agron., 26(4), 7-13.

4. Beutler A.N., Centurion J.F., Silva A.P. 2014. Intervalo hídrico ótimo e a produção da soja e arroz em dois Latossolos. Irriga, 9, 181-192.

5. Buliński J., Marczuk T. 2009. Ocena odziaływania na glebę kół agregatów ciągnikowych w gospodarstwach rolniczych. Inżynieria Rolnicza, 1, 53-59.

6. Buliński J., Sergiel L. 2011. Wpływ wilgotności gleby na jej zagęszczenie kołem ciągnika. Inżynieria Rolnicza, 8(133), 45-51.

7. Busscher W.J., Bauer P.J., Camp C.R., Sojka R.E. 1997. Correction of cone index for soil water content differences in a coastal plain soil. Soil and Tillage Research, 43(3), 205-217.

8. Dexter A.R., Czyż E.A, Vizitiu O. 2007. A method for prediction of soil penetration resistance. Soil and Tillage Research, 93(2), 412-419. 
9. Halecki W., Kruk E., Ryczek M. 2018. Estimations of nitrate nitrogen, total phosphorus flux and suspended sediment concentration (SSC) as indicators of surface-erosion processes using an ANN (Artificial Neural Network) based on geomorphological parameters in mountainous catchments. Ecological Indicators, 91 (2018), 461-469

10. Lejman K., Owsiak Z., Szewczyk A. 2010. Wpływ energii zagęszczania na zmiany zwięzłości gleby. Inżynieria Rolnicza, 5(123), 121-128.

11. Li Y., Wang C., Tang H. 2006. Research advances in nutrient runoff on sloping land in watersheds. Aquatic Ecosystem Health and Management, 9, 27-32.

12. Małecka I., Blecharczyk A., Sawińska Z., Piechota T., Waniorek B. 2012. Plonowanie zbóż W zależności od sposobów uprawy roli. Fragm. Agron., 29(1), 114-123.

13. Medeiros. J.C., Figueiredo G.C., Mafra Á.L. 2010. Portable penetrometer for agricultural soil: sensitivity test to identify critical compaction depth. R. Bras. Ci. Solo, 34, 1823-1829.

14. Mocek A. 2015. Gleboznawstwo. Wydawnictwo Naukowe PWN SA, Wydanie 1, Warszawa

15. Powałka M. 2009. Ugniatanie gleby obniża plony. Agromechanika, 6, 22-25.
16. Price R.R., Theriot J. 2003. Development of a frame to automatically insert a hand-held penetrometer. ASAE Meeting Paper No. 031077, St. Joseph, MI, USA

17. PTG. 2008. Klasyfikacja uziarnienia gleb i utworów mineralnych

18. Rudnicki F. 1992. Doświadczalnictwo rolnicze. Wyd. ATR Bydgoszcz

19. Szeptycki A. 2003. Wpływ ciężkich maszyn rolniczych na fizykomechaniczne właściwości gleby. Journal of Research and Applications in Agricultural Engineering., 48(2), 38-42.

20. Wesołowski M., Cierpiała R. 2011. Plonowanie pszenicy ozimej w zależności od sposobu wykonania uprawy przedsiewnej. Fragm. Agron. 28(2), 106-118.

21. Włodek S. 2000. Wpływ powierzchniowego zagęszczania gleby na jej właściwości fizyczne w profilu. Komitet Techniki Rolniczej PAN, Polskie Towarzystwo Inżynierii Rolniczej. IBMER Wrocław, 313-318.

22. Zbytek Z., Talarczyk W. 2012. Sposoby ograniczania negatywnego oddziaływania agregatów ciągnikowych na rolę. Problemy Inżynierii Rolniczej, 4(78), 57-68. 